\title{
Reproductive and developmental hazards and employment policies
}

\author{
J Don Johnston, Geoff G Jamieson, Susan Wright
}

\begin{abstract}
The task of informing workers of hazards in the workplace is seldom more difficult than with the subject of reproductive and developmental hazards. Occupational health staff and physicians are faced with a paucity of relevant medical information. Workers, kept aware of the thalidomide spectre with every media report of the latest descriptive epidemiology study, are anxious to know more. Employers, knowing that few agents are regulated on the basis of reproductive hazards, are encouraged to lessen workplace exposure to all agents but need guidance from government and scientists in setting priorities. Understandable ethical and scientific limitations on human studies require researchers to study animals and cells. The difficulties of extrapolating the results of this research to humans are well known. The scientific, medical, and workplace difficulties in dealing with reproductive and developmental hazards are mirrored in the regulatory positions found in North America. Some regard fetal protection policies as sex discrimination whereas others consider such policies as reasonable. Guidelines are provided to allow employers and medical practitioners to consider this difficult problem.
\end{abstract}

A 26 year old laboratory technician (para 2) presented at eight weeks gestation for advice about workplace health risks to her fetus if she continued work. Two years earlier while employed, she had a stillborn infant at 36 weeks and, as her job remained the same, she was concerned that continuing her work could adversely affect the fetus. Neither she nor her husband had any known risk factors that might affect pregnancy according to an assessment made by her obstetrician.

Occupational and Environmental Health, NOVA Corporation of Alberta, PO Box 2535, Station M, Calgary, Alberta, Canada T2P 2N6

J D Johnston, G G Jamieson, Susan Wright
Worksite evaluation showed good work practices, proper ventilation, and good personal protection. None of the chemicals used were known reproductive hazards. The employer, although reluctant to reassign pregnant employees, was willing to do so if this should be recommended by the employee's doctor.

She discussed the situation with her doctor and the occupational health clinic physician and decided to continue work.

At 14 weeks she had a spontaneous abortion and resigned shortly afterwards. She stated that she would not work with chemicals again until she had finished having children. Although she acknowledged that her work likely had nothing to do with the spontaneous abortion, she felt very guilty that she had remained at work. The physicians wondered if they had erred: Had the worksite been properly assessed? Did they have the best available information about potential hazards? The employer also had doubts: Would he have risked being charged with discrimination on the basis of sex if he had reassigned this employee? If he had no position to reassign her to, would he have been obliged to put her on paid sick leave even though she was not ill?

Health professionals, particularly family physicians, face one of the most problematical tasks in medicine: assessing and explaining the risk of exposure to a suspect workplace agent when the background (natural) incidence of adverse effect is very high. Each media report ${ }^{1}$ associating a birth defect with yet another workplace or environmental agent revives the spectre of thalidomide. Unfortunately, good science does not ensure that a product falsely labelled as a teratogen (as was Bendectin ${ }^{2}$ ) will be acceptable to a public aroused by news media accusations to the contrary.

The dilemma faced by the workers and the physician is mirrored by the employer's enigma. On the one hand he is obliged to provide a safe workplace, but the degree of risk from worker exposure is questionable even for identifiable reproductive and developmental hazards. Then too, on the one hand he cannot deny employment on the basis of sex, but if harm comes to the fetus or offspring of the worker as a result of workplace activities, the employer is open to suit for damages. 
Recent publications confirm the reality of the problem and the extent of concern. ${ }^{34}$ The purpose of this presentation is to review what is known of the scientific aspects of the situation and the existing Canadian regulatory scene, and to offer a pro tem imperfect but practical approach for considering problems in the workplace.

\section{Terminology}

The recent surge in reproductive technological breakthroughs has been accompanied by changes in terminology. Reproductive hazards, ${ }^{5}$ formerly defined as any hazard to conception and development in utero (and, to some extent, postnatally) is now restricted to hazards which interfere with or prevent conception.

Reproductive hazards are distinct from developmental hazards ${ }^{6}$ the potential effects of which serve to define the term-namely, hazards which produce structural abnormalities, functional deficits, pathological alterations to growth, or death. Developmental hazards may act or show effects at any point of development between the time of conception and the onset of puberty.

The distinction made between a reproductive hazard and a developmental hazard assists the health professional in assessing hazards of the workplace by effectively dividing them into those affecting the worker and those affecting the fetus or young child. The implications for potential recovery from their effects are different for each: the effects of exposure to reproductive hazards (impotence, sterility, etc) are sometimes reversible; developmental hazard effects are almost invariably permanent.

An example of a reproductive hazard is the nematocide DBCP (1,2-dibromo-3-chloropropane), which causes male sterility. ${ }^{7}$ Examples of developmental hazards are: rubella

(produces structural abnormalities)

diabetes mellitus (produces growth alteration) lead (produces functional deficit). ${ }^{8}$

Ionising radiation causes sterility and fetal death and is thus both a reproductive and developmental hazard. ${ }^{9}$

Clearly, reproductive hazards in the workplace are relevant as such only when workers who have the potential of initiating conception are exposed to them. Developmental hazards, on the other hand, are of significance to pregnant workers and, in some cases, to workers who are breast feeding a child ${ }^{10}$ or who have young children at home. The product of conception is vulnerable to a developmental hazard only at certain stages of in utero development. Figure 1 illustrates how the period of in utero vulnerability varies for several such hazards.

A birth defect (also known as a congenital anomaly or malformation) is any structural, functional, or biochemical abnormality, whether genetically determined or otherwise, that is not produced by birth trauma. As we shall see, lack of consensus about the recording of birth defects has contributed greatly to confusion and uncertainty about their true incidence. Nevertheless, the definition as presently expressed will serve us well in achieving an understanding of this complex issue.

\section{Epidemiological evidence of birth defects}

Large scale malformation surveillance programmes are important sources of data on the occurrence of congenital malformations. Through such surveillance in France the association was established between neural tube defects and valproic acid, a drug used to treat epilepsy. Similar surveillance systems, like the American Birth Defects Monitoring Programme and The Canadian and Alberta Congenital Anomalies Surveillance System, ${ }^{11}$ provide background incidence and prevalence rates. Without these baseline data, the detection of changes in frequency is speculative at best. Also, surveillance data can provide reassurance about the absence of problems. Registries of birth defects were set up after the thalidomide tragedy. Before this, few data were available for epidemiological studies and detection of new defects or changes in frequency were the realm of the astute clinician. In fact, it remains likely that such clinicians will note a new teratogenic effect before it is evident in a passive surveillance system. ${ }^{12}$

About $7 \%$ of live born infants in the United States are afflicted with a birth defect. ${ }^{12}$ Canadian and British registries show similar results. Estimates in other studies are as low as $3 \%$, but comparisons between populations require careful examination of how data are defined, how they were obtained, and what is recorded as a defect. As an illustration, some registries include undescended testes but others exclude this finding. ${ }^{12}$ Similar discrepancies in inclusion and exclusion criteria are found with patent ductus arteriosus and mild orofacial clefting. Comparisons also require knowledge of the gestation and whether premature infants are included as well as babies more than one year of age. Improper coding may also be a source of difficulty in making valid comparisons.

Regional variations in rates of congenital anomalies may reflect the common phenomenon of gradations of medical services. Babies born in referral hospitals reflect the high risk nature of their obstetrics in a high rate of congenital anomalies; the converse being the relatively healthy, low risk pregnancy cared for in a non-referral hospital.

Analysis of data from the Alberta Congenital Anomaly Surveillance System shows the prevalence rates of the somewhat rural city of Fort McMurray (population 33698 ) at $14 \cdot 72$ per 1000 live births. ${ }^{12}$ By 
Figure 1 Human developmental stages and susceptibility of organ systems to reproductive and developmental toxicants (with permission of Dr J Doull).

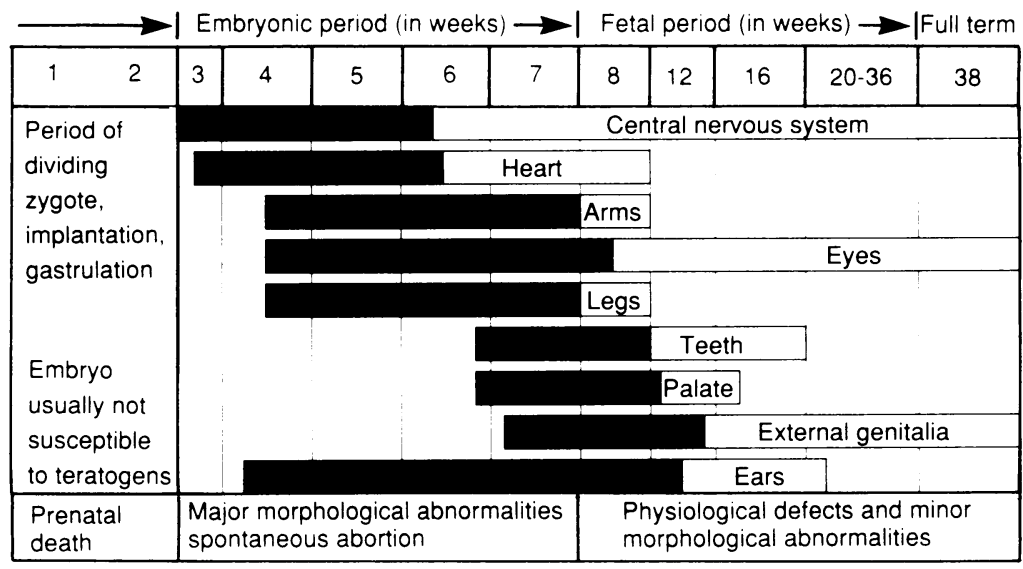

comparison, Calgary (population 692 000), a major referral centre, has a rate more than triple that at 49.02 per 1000 . The investigators point out that they cannot account for the very low rate in Fort McMurray but note that it is a young community of healthy couples.

Boys account for more than half of all infants with congenital anomalies. As well, multiple defects are common with $21 \%$ of those reported to the Alberta Surveillance Programme having two or more congenital anomalies.

The consistency of rates over the years may indicate a steady state about which little can be done. Birth defects cause nearly one third of all deaths in Canada before 1 year of age, and nearly a quarter before age 15 (the proportion of infant deaths due to birth defects). Birth defects rank sixth among causes of potential years of life lost (PYLL) in Canada. Although PYLL does not estimate quality of life, it provides a public health measure for comparisons when setting health care priorities. ${ }^{13}$

\section{Evidence for workplace hazards from epidemiological studies}

Canadian and American estimates correspond in finding no identified causes for more than $60 \%$ of all birth defects. Genetic causes account for 15-20\%, maternal metabolic disease (for example, diabetes) 3$5 \%$, and drugs and environmental chemicals 2$3 \% .^{1415}$

Epidemiology can identify infertility and congenital anomaly patterns in populations, but ethical considerations and the lack of good endpoints limit studies of the fetus in utero. ${ }^{10-18}$ The inferences possible from recent studies relating the outcome of pregnancy with parental occupation will prove difficult to interpret to patients familiar with the studies and who work at the occupations associated with adverse reproductive and developmental outcomes. ${ }^{19-21}$ Unfortunately, many descriptive studies that show positive findings are characterised by bias, often as a result of poorly designed questionnaires. ${ }^{22}$

Recent examples of studies of developmental disorders with regard to parental occupation are: childhood leukaemia and nuclear installations, ${ }^{23}$ solvent exposure and anencephaly, ${ }^{24}$ spontaneous abortion and solvents, ${ }^{25}$ cardiac septal defects and employment as a fireman, ${ }^{26}$ perinatal deaths and leatherwork, ${ }^{27}$ and pesticides and haemangiomas. ${ }^{28}$ Certainly the most significant of these studies is that which associated childhood leukaemia with the fathers' employment at the nuclear plant in Sellafield, England. ${ }^{2329}$ The results of this case-control study are at odds with the much larger study of the children of Japanese men who survived the atomic bomb explosions. ${ }^{30}$ If the British study has truly shown a link between childhood leukaemia and the fathers' exposure to ionising radiation, there are great implications for other workplaces and for other agents that damage male germ cells.

Epidemiological studies of exposure to anaesthetic gases and pregnancy outcome ${ }^{31}$ have found an increase in spontaneous abortions among women exposed to these gases in hospitals and dentists' offices. Exposure to anaesthetic gases is frequently higher than expected because of leaks in the equipment and poor maintenance of scavenging systems. ${ }^{32}$ Biological monitoring of exposure to nitrous oxide in surgical areas has shown good correlation between the ambient concentrations of nitrous oxide and concentrations of the gas in urine and expired air. Few chemicals can be monitored so readily.

\section{MALE MARKERS}

Necessary limitations to carrying out agent effect studies on the human fetus dictate the use of animal subjects to a far greater extent than in virtually any 
other area of medicine. The same is not true, however, for studies of sperm. Traditional sperm studies, such as sperm count, mobility, and morphology, have historically been subjective measures that vary within each man and considerably among individual subjects. ${ }^{15}$ Although of limited value in the occupational area, they have nevertheless proved useful in the follow up of azospermic and oligospermic workers who had been exposed to 1,2-dibromo3-chloropropane. ${ }^{1533}$ The study by Levine et al of the sperm of normal men working outdoors in Texas during the summer and winter found changes that may partly explain the deficit of births during the spring season in warm climates. Decreases between $24 \%$ and $32 \%$ were noted for sperm count, sperm concentration, and concentration of motile sperm in the summer. ${ }^{34}$

The use of biomarkers in sperm studies will improve the sensitivity and specificity of measures of physiological and genetic damage. ${ }^{15}$ As men account for about $40 \%$ of infertility in couples and the extra chromosome in children with Down's syndrome originates with the father in $25-50 \%$ of the cases, ${ }^{15}$ improved biomarkers of genetic damage in sperm or offspring will greatly improve our understanding of some reproductive and developmental hazards. Meanwhile, in the absence of practical biomarkers, no efficient mammalian tests exist for studying germinal mutations. Instead, germinal mutagenicity is tested in mice: a serious limitation since only about 30 of the 60000 or more chemicals in the United States and Canada have been studied for germinal mutagenicity. ${ }^{35}$ Until practical biomarkers of genetic damage and heritable mutations are developed for the male germ line, hazard identification and risk assessment in the workplace will remain woefully inadequate. This inadequacy is heightened by the fact that the other half of the genetic package of conception, the egg, will never provide the opportunity for studies that are possible with sperm. Because of the necessary restrictions on the study of the human fetus, hazard identification and risk assessment is largely done on animals. ${ }^{16}$ The next section reviews significant aspects of animal studies.

\section{Animal toxicological evidence of birth defect hazards}

Because of the technical and ethical limitations of fetal study, reliance on animal studies to assess reproductive and developmental hazards will be much greater than in most fields of medicine. Studying the human embryo after the appearance of the primitive streak is prohibited in most countries. In fact, pressure exists from some groups to completely prohibit research on fertilised human eggs. ${ }^{16}$ The benefits from research using fertilised human eggs and embryos will no doubt justify some research but the controversy will make animal toxicology the likely alternative.

Extrapolating the results of animal reproductive and developmental toxicology to identify human hazards will exceed the well known difficulties in mutagenesis and carcinogenesis when extrapolating from animal research to humans. Exceptions exist, however, as noted in the next section.

\section{CONSIDERATIONS OF PATHOLOGY}

Morphological factors

Laboratory studies of reproduction in animals have provided much information of benefit to humans; hormonal contraceptive work being a prime example. Animal studies are also the mainstay in the evaluation of possible teratogenic effects of medications, a practice for which there is no present alternative. There are dangers, however, in drawing single conclusions from animal studies, a problem that became evident in the testing of the sedative thalidomide. Mice and rat embryos were not harmed by doses 10 times higher than the clinical and teratogenic dose in human subjects. ${ }^{36}$ The tragic results of direct dependence on an animal study have resulted in greater attention to interspecies organogenetic differences.

The commonly used test species, mice and rats, have much shorter periods of organogenesis than humans (table 1). Hence, the time of exposure to an agent that may cause a developmental effect in a mouse or rodent fetus is crucial because of the brief time (maybe less than a day) during which the developing organ is susceptible. If this susceptible period is missed, say due to a weekend laboratory closure, a positive effect may be missed. Negative results may thus provide false reassurance of the safety of the compound. The mouse cerebellum, for example, is adversely affected by the antimitotic cancer drug 5-azacytidine only by treatment on embryonic day $12 .^{37}$

\section{Metabolic factors}

Coincident with the morphological changes of organogenesis are fetal metabolic developments such as the Krebs cycle. ${ }^{38}$ Enzyme development is of particular interest because of the role of some enzymes in the activation of chemicals to a toxic form. This phenomenon of metabolic activation is well known in cancer research and is used routinely in the Ames test.

Discovering similar metabolic activation in the fetus has been anticipated, but animal fetuses tend not to have concentrations of activating enzymes as high as those in the human fetus (table 2 ).$^{38}$ Hence, studies of a possible effect using animals may not be an adequate means of study if metabolic activating enzymes are too low in the animal to produce the toxin. By contrast, the same enzyme in the human 
Table 1 Periods of organogenesis in various species

\begin{tabular}{llllc}
\hline Species & $\begin{array}{l}\text { Blastocyst } \\
\text { formation } \\
\text { (days) }\end{array}$ & $\begin{array}{l}\text { Implantation } \\
\text { (days) }\end{array}$ & $\begin{array}{l}\text { Organogenesis } \\
\text { period } \\
\text { (days) }\end{array}$ & $\begin{array}{l}\text { Duration of } \\
\text { gestation } \\
\text { (days) }\end{array}$ \\
\hline Mouse & $3-4$ & $4-5$ & $6-15$ & 19 \\
Rat & $3-4$ & $5-6$ & $6-15$ & 22 \\
Monkey (Rhesus) & $5-7$ & $9-11$ & $20-45$ & 164 \\
Human & $5-8$ & $8-13$ & $21-56$ & 267 \\
\hline
\end{tabular}

Adapted from presentation of Jeanne M Manson at the Society of Toxicology 29th annual meeting Miami Beach, Florida, 1990.

fetus could be present at concentrations sufficient to cause damage.

\section{Chromosomal and biochemical factors}

Animal toxicology permits the study of the mechanisms of actions of embryotoxic chemicals. Studies of the fetotoxic effects of 2-methoxyethanol (2-ME) at the Chemical Institute of Industrial Toxicology have shown some interesting malformation attenuating effects of serine in mice. ${ }^{39}$ The incidence of digit malformations in near term mouse fetuses is decreased significantly if serine is given to the exposed pregnant mouse. It is hypothesised that the fetotoxic effect of $2-\mathrm{ME}$ is due to impaired purine biosynthesis. Serine may decrease this effect by providing the precursors required in the repair process.

Other animal studies have found unexpected associations between the outcome of pregnancy and biochemical markers. For example, in studying the high incidence of congenital malformations and diabetes, Sadler ${ }^{40}$ has found that low blood sugar concentrations and ketosis in mice are associated with an increased incidence of malformations in offspring. It remains speculative as to whether similar associations exist in humans. If low blood sugar and ketosis are factors in humans, there could be implications for the management of diabetic patients. No evidence exists yet that other fetal toxins interact in diabetic mice to produce more malformations than either the toxin or the diabetes.

The central nervous system

Until recently, studies of fetal central nervous system

Table 2 Appearance of xenobiotic biotransforming enzymes in fetal liver

\begin{tabular}{llll}
\hline Species & $\begin{array}{l}\text { Organogenesis } \\
\text { period } \\
\text { (days) }\end{array}$ & $\begin{array}{l}\text { Cytochrome P-450 } \\
\text { (\% of adult } \\
\text { concentration) }\end{array}$ & $\begin{array}{l}\text { Birth } \\
\text { (days) }\end{array}$ \\
\hline Rat & $6-15$ & $0-5$ & 22 \\
Mouse & $6-15$ & $0-4$ & 19 \\
Guinea pig & $10-18$ & $6-30$ & 66 \\
Macaque & $20-45$ & $10-20$ & 170 \\
Human & $21-56$ & $20-40$ & 267
\end{tabular}

Adapted from the presentation of Jeanne M Manson at the Society of Toxicology 29th annual meeting. toxicity were limited to observations of morphological and anatomical changes. Using these measures, researchers identified the emergence of the parts of the central nervous system and the exposure related susceptibility of the developing organ to toxins. Recent progress in cellular and molecular research has provided more sensitive tools for the study of toxins. Early studies of the chronological development of drug binding sites in the fetal rat brain indicate that parallels exist in the emergence and susceptibility of binding sites similar to those of morphological organogenesis. ${ }^{41}$ Similarly, development of some central nervous system binding sites continues after birth as does the anatomical development of the brain. Figures 2 and 3 indicate the corresponding chronology of emergence of binding sites and neurons.

Neonatal and early developmental measures, such as passive avoidance and hypo and hyperactivity, have provided toxicologists and clinical researchers with tools to study the functional effects of prenatal toxins. Seldom have new markers of effect had such important applications in the assessment of human toxicity. Non-industrial chemicals such as those used by drug abusing mothers are known to affect the behaviour of the neonate. ${ }^{42-45}$ Exposure to lead during pregnancy may also affect the developing brain, which is made clearly evident in behavioural changes of the

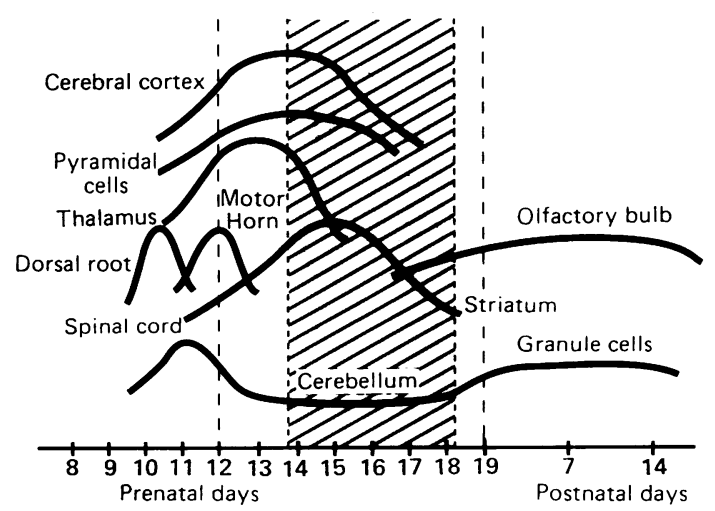

Figure 2 Chronology of neurone production in mouse central nervous system. Various agents led to hyperactivity of mothers treated during the period marked by shading (adapted from Rodier PM. Dev Med Child Neurol 1980;22:525.). 


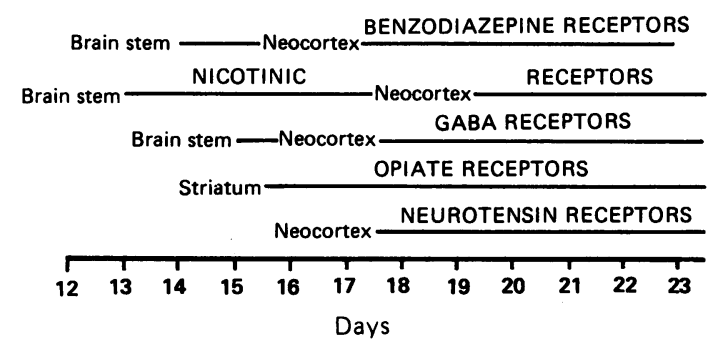

Figure 3 Development of drug binding sites and neurotransmitter sites in fetal rat brain (adapted from

Lichensteiger $W$, Ribary $U, S$ chlumpf $M$, Odermatt $B$.

Prenatal adverse effects of nicotine on the developing brain. Prog Brain Res 1988;73:137-57).

infant. ${ }^{46}$ Lead concentrations in breast milk have a roughly $1: 1$ correlation with lead concentrations in maternal blood. Perchloroethylene, however, has a concentration three times higher in breast milk than maternal blood and polychlorinated biphenyl concentrations range between four and 10 times higher in breast milk than in maternal blood. ${ }^{10}$

No placental fetal barrier exists to transport of lead and maternal and fetal blood lead concentrations are similar. ${ }^{47}$ Concentrations previously thought to be safe are under review using the new markers of effect, which in clinical research are represented by the Bayley Mental Development Index. ${ }^{8}$ Scores at six, 12,18 , and 24 months show decrements in lead concentrations that were lower than those in earlier studies and which showed no or minimal effects. One hypothesis is that fetal exposure may produce an effect at a concentration that has little effect after birth. If so, the currently accepted maternal blood lead concentrations should be lowered. This is even more critical because of the release of bone lead stores during pregnancy adding to the exposure of the fetus in utero. Thus the increased susceptibility of the fetus and physiological mobilisation of lead during pregnancy should result in a lowering of acceptable concentrations of maternal blood lead. ${ }^{48}$

These outcomes appear to be due to receptor and transmitter changes and not to the better known cellular toxicity caused by agents such as ionising radiation and methyl mercury.

Seldom has there been such early fruitful interaction between basic science and clinical medicine. The lesson, that of fetal toxicity occurring at concentrations that may be safe for the adult, must be introduced as a guide in workplace exposures and employment assessments.

The law and reproductive and developmental hazards in the workplace

Reproductive and developmental health protection policies deal with some of the most complex issues in science and law. The rights of an employee to decide whether or not to participate in hazardous work are considered by some as allowing a mother to make a decision regarding exposure on behalf of her fetus. Furthermore, any employer considering the implementation of a reproductive hazards policy is put in the difficult position of choosing between two conflicting objectives. ${ }^{49}$ The first is to create a nondiscriminatory workplace and the second is to avoid exposing fertile female employees to reproductive and developmental hazards. A review of the Canadian and American cases in this area produces the following principles:

\section{(1) Reproductive and developmental policies are discriminatory}

Any discrimination of an employee on the basis of a sex specific reproductive and developmental policy is characterised at law as prima facie discrimination on the basis of sex and is prohibited by the federal and provincial human rights legislation unless justified by a bona fide occupational qualification. Furthermore, such policies are characterised as discriminatory even if the employer does not intend to discriminate; the mere fact that the policy excludes a group of employees from certain jobs on the basis of sex is enough for a finding of discrimination that must be justified by the bona fide qualification defence.

\section{(2) The bona fide occupational qualification defence} A fetal protection policy is justifiable if the employer shows that such discrimination is a bona fide occupational qualification reasonably necessary to the normal operations of the business. The Supreme Court of Canada has held that to be a bona fide occupational qualification, a limitation " . . . must be imposed honestly, in good faith, and in the sincerely held belief that such limitation is imposed in the interests of the adequate performance of the work involved with all reasonable dispatch, safety and economy and not for the ulterior or extraneous reasons aimed at objectives which would defeat the purpose of [human rights legislation]. In addition, it must be related in an objective sense to the performance concerned in that it is reasonably necessary to ensure the efficient and economical performance of the job without endangering the employee, fellow employees and the general public." ((Ontario Human Rights Commission v Borough of Etobicoke) (1982) 132 DLR 3d 14 SCC at 19.)

THE ELEMENTS OF THE BONA FIDE OCCUPATIONAL QUALIFICATION DEFENCE

No Canadian cases challenge an employer's fetal protection policy; however, the issue has been considered by the American courts. The leading case is the recent decision of the United States Supreme 
Court in International Union, UAW v Johnson Controls Incorporated (1991). In that case, the Court ruled in favour of the petitioners who challenged the policy of Johnson Controls, which barred fertile women from jobs that exposed them to lead.

Justice Blackmun, speaking for the majority of the Court, reviewed the bona fide occupational qualification definition set out in Title VII of the Civil Rights Act of 1964, which states that an employer may discriminate on the basis of sex in those cases in which sex is a bona fide occupational qualification reasonably necessary to the normal operation of a particular business. Title VII was amended by the Pregnancy Discrimination Act, which specifies that unless pregnant employees differ from others in their ability or inability to work they must be treated the same as other employees for all employment related purposes. The Court held that these statutes and the case law prohibit an employer from discriminating against a woman because of her capacity to become pregnant unless her reproductive potential prevents her from performing the duties of her job. Because women could manufacture batteries as efficiently as anyone else, Johnson Controls could not rely on the bona fide occupational qualification defence and its fetal protection policy was struck down.

Whereas the majority decision sets out the law, its impact may have been restricted somewhat by a concurring opinion written by Justice White who agreed with the majority decision with respect to Johnson Controls, but did not agree that the bona fide occupational qualification defence is so narrow that it could never be used to justify a sex specific fetal protection policy. Justice White argued that such a policy would be justified if an employer could show that the exclusion of women from certain jobs was reasonably necessary for an employer to avoid substantial tort liability to their children.

Justice White listed four reasons why the Johnson Controls policy failed, and in so doing provided some guidance as to when such a policy may succeed. These reasons were as follows:

(1) Although Johnston Controls showed a high risk that fetal injury would occur in the absence of a fetal protection policy, Johnson Controls failed to consider the extent of fetal injury likely to occur. The fetal protection policy would not be a bona fide occupational qualification if it sets a risk-avoidance level substantially higher than other risk levels tolerated by Johnson Controls.

(2) The fetal protection policy of Johnson Controls was too far reaching because it excluded all fertile women regardless of age and excluded women from positions that might lead to a promotion to a position in which there would be a high lead exposure.

(3) Before 1982, Johnson Controls operated without an exclusionary policy; however, it failed to show grounds for now implementing the exclusionary policy-for example, that the risks of fetal harm or the costs associated with fetal harm had substantially increased since 1982.

(4) Johnson Controls should not have succeeded in the lower courts because the lower courts applied the "business necessity" test. This was the wrong test and it improperly placed the burden of proof on the petitioners and not Johnson Controls. The proper test is the bona fide occupational qualification test which places the burden of proof squarely on Johnson Controls. As a result, the lower courts failed to properly consider the petitioners' evidence of harm to offspring caused by exposure to lead in men.

\section{IMPACT OF JOHNSON CONTROLS IN CANADA}

The Canadian courts have not yet heard a challenge to an employer's fetal protection policy. Before the Johnson Controls case it appeared that the Canadian courts would have upheld an employer's fetal protection policy as a bona fide occupational qualification, provided that it met certain carefully defined parameters. The Canadian Human Rights Commission has reviewed several claims of discrimination based on fetal protection policies and has allowed the policies to stand when it has been shown that such discrimination is justified by a bona fide occupational qualification defence. The Commission has required statistical and medical evidence of the effect of hazardous substances on the fetus and evidence that no reasonable alternative to the fetal protection policy is available that would not create undue hardship on the employer. The Commission has recommended a variety of settlements depending on the facts in each case. These include reassignment of affected women to less hazardous positions accompanied by remuneration protection, the enforcement of reformed standards including the reduction of exposure levels to protect pregnant women from exposure to hazardous substances and layoffs when available reassignment positions are lacking. This approach is consistent with the earlier American cases; however, the recent Johnson Controls decision has injected an element of uncertainty into the Canadian context.

American decisions, although not binding on Canadian courts, are often persuasive and will be given due consideration by the Canadian courts, especially if there is a dearth of Canadian case law in the area. It should be noted at the outset, however, that as well as being a foreign judgement, the Johnson Controls case was heard in the context of a more comprehensive legislative background (Title VII and the Pregnancy Discrimination Act) and the American bona fide occupational qualification defence is somewhat different from the Canadian bona fide occupation qualification test, which links "adequate perform- 
ance" of work with the criteria of "reasonable dispatch, safety, and recovery."

As a result of distinctions, it is hoped that given a choice between the decision of Justice Blackmun for the majority of the Court and that of Justice White, a Canadian court would find Justice White's decision more persuasive, primarily because of his more realistic assessment of the real risk to an employer of a lawsuit for prenatal injuries. In any event, a Canadian employer would be well advised to carefully consider the shortcomings in the Johnson Controls fetal protection policy, as highlighted by Justice White, before implementing a sex specific fetal protection policy.

\section{VOLUNTARY ASSUMPTION OF RISK OF EXPOSURE} Should an employee be given the choice of assuming the risk of exposure after executing a release which would, at face value, release the employer from all liability to both the employee and her child with respect to reproductive and developmental hazards resulting from the employees choice to continue working in a hazardous area? A review of the case law in both Canada and the United States indicates that this proposal has very little merit.

The Manitoba Human Rights Commission has held that an employee has no right to assume the risk of serious injury to himself. Furthermore, it is doubtful whether at law a pregnant woman could execute a release of liability on behalf of her unborn child because the law does not recognise a fetus as a person and will not recognise a cause of action for preconceptual injury until birth. In other words the release with respect to the child would likely be meaningless.

Also, a court will not impute a mother's contributory negligence to her child to reduce the employer's liability. Therefore, an employer risks being held liable for full common law damages for personal injury in the event that the child was successful and would be unable to rely on the defence of contributory negligence or the protection provided by workers' compensation legislation, which considers only injury to the employee, not her child.

\section{WORKERS' COMPENSATION}

Workers' compensation in Canada does not provide benefits for most reproductive and developmental problems because it covers personal injury to the worker. Unless a worker meets the criteria regarding occupational injury or illness-pregnancy does not qualify-then benefits will not be paid. An exception is Quebec where the protective reassignment programme for expectant and nursing women ensures benefits when reassignment is not possible. ${ }^{47}$ This approach, considered enlightened by many, may also be inspired by an overall policy with financial incentives in Quebec to increase the birthrate.

\section{TENTATIVE SOLUTIONS}

The following guidelines have been prepared for the assessment of hazards relative to reproductive and developmental risks in the workplace. It is clearly not possible to have a "no risk" environment, but it is possible to control exposures so that risk is minimised. $^{50-52}$ The regulation of chemicals because of their damaging reproductive or developmental effects is unusual, however; the United States regulates only three on this basis-namely lead, DBCP, and ethylene oxide. Biological reproductive hazards, unlike chemical and radiation hazards, tend not to be regulated at all but are covered under recommendations like that of the Canadian Pediatric Society concerning cytomegalovirus. Regarding day care centres and risk to pregnant staff, the Society position paper states: "Should pregnant women be excluded from working in day-care centres? No, . . . adherence to hand washing . . . should be sufficient."

Employees, employers, and physicians are referred to the excellent publication For a safe maternity experience published by the Quebec Commission de la santé et de la sécurité du travail. ${ }^{54}$ This publication does not cover men or non-pregnant women, but otherwise does provide a well developed programme that includes benefits payments under some circumstances. A list of 200 suspected and known reproductive and developmental hazards was developed for the California Proposition 65 Scientific Advisory Panel (SAP). ${ }^{55}$

The approaches used in selecting the 200 agents ranged from identification of agents in validated scientific publications to a risk estimate from the integration of toxicity and exposure data. Nonindustrial agents such as cannabis and caffiene were considered as potential reproductive toxicants by the SAP.

\section{EMPLOYEE GUIDELINES}

(1) Obtain information from government, labour, industry, and medical organisations on policies, practices, and resources regarding reproductive and developmental hazards in the workplace. ${ }^{475556}$

(2) Ensure that "right to know" provisions include reproductive and developmental hazards.

(3) Identify reproductive and developmental hazards in the workplace using the resources noted in guideline (1) above.

(4) Know the acceptable levels of exposure to the chemical, physical, and biological agents in your workplace.

(5) Know the control methods-substitution; safe work practices/procedures; personal protective equipment. 
(6) Know the company programme for job reassignment.

(7) Be aware of the Workers' Compensation implications regarding reproductive health.

EMPLOYER GUIDELINES ${ }^{5058}$

(1) Establish criteria for the identification and assessment of reproductive and developmental toxins.

(2) Establish an inventory of known and suspected reproductive and developmental toxins used or produced in the workplace.

(3) Develop and maintain a central file on all suspected reproductive and developmental toxins and products handled at all work sites. This file should include data from publication search, information from suppliers, toxicological, and epidemiological studies.

(4) Identify routes of workplace exposure-inhalation; skin absorption; ingestion; eye contamination.

(5) Determine acceptable levels of exposure applicable to the chemical, physical, and biological agents that have been identified.

(6) Determine control methods-Substitution; engineering controls; administrative controls; work procedures/practices; personal protective equipment.

(7) Develop a hazard communication programme. Develop education programmes to inform employees of those agents that may represent potential risks to the male and female reproductive systems as well as to the developing fetus. Inform them of the workplace procedures intended to protect employees against overexposure. Medical personnel, hygienists, and toxicologists should be involved in the communication process when chemical, physical or biological agents have been found to be potential developmental or reproductive toxins. These employee communications should be clearly written and made available to employees. They should also be updated as new toxicological and epidemiological information becomes available.

(8) Consider a reproductive and fetal protection policy. Adverse effects of toxins on the fetus or to the reproductive capacity of male and female employees can be prevented by the control measures outlined in sections 6 and 7 earlier. Assess the risk to the fetus and worker, considering normal background risk factors such as age and other predispositions. If increased risk exists, establish a policy of protection that is selective in its application, avoiding blanket policies that may be discriminatory because they cover all fertile women and not just those at risk. Do not extend a protection policy to jobs which in and of themselves are not hazardous. Clearly identify the options and procedures of fetal protection policies with regard to employment and benefits. If reassignment of a female worker of reproductive potential is made after the recognition of unacceptable development risk to the fetus in the workplace, such reassignment should be made in accordance with any applicable regulations and the employer's policy.

(9) Dependence on a positive pregnancy test as the criterion for reassignment is discouraged because the fetus is very susceptible to toxins during the first 12 weeks of development, a period when women are most likely not to be aware of their pregnancy and, hence, not yet tested.

GUIDELINES FOR HEALTH PROFESSIONALS $S^{56} 57$

Health professionals face increasing difficulties in advising patients about continuing work in an environment that is generally considered safe with regard to reproductive and developmental health but in which there are many unknowns. Even in the safest environment, $3-6 \%$ of babies will inevitably have a malformation. Parents, particularly mothers, may blame themselves for continuing work that might have contributed to their child's deformity. However minuscule the risk, the mother's doubt and guilt may persist. Doctors and nurses share these anxieties and doubts for they are the principle advisors to the prospective parents and will introspectively wonder if they could have given poor advice through ignorance of the workplace. Health professionals must prepare themselves for this difficult role by learning more about developmental hazards. The high background incidence of anomalies only emphasises the necessity of continued attention to the provision of good prenatal care, a requirement which must include careful consideration of the patient's workplace.

1 Richards B. Fathers chemical contacts linked to pregnancy woes. The Wall Street Journal, 6 July 1989.

2 Smithells RW, Sheppard S. Teretogenicity testing in humans: a method demonstrating safety of bendectin. Teratology 1978;17:31-5

3 Taskinen HK. Effects of parental occupational exposures on spontaneous abortion and congenital malformation. Scand $J$ Work Environ Health 1990;16:297-314.

4 Office of Technology Assessment Taskforce. Reproductive health hazards in the workplace. Philadelphia: JB Lippincott Company 1988.

5 Proposed guidelines for assessing female reproductive risk. Washington DC: 53 Federal Register 24834, June 1988. (Environmental Protection Agency Notices No FRL 3401-1.)

6 Proposed guidelines for assessing male reproductive risk. Washing- 
ton DC: Federal Register 248050, June 1988. (Environmental Protection Agency Notices No FRL 3401-5.)

7 Paul M, Himmelstein J. Reproductive hazards in the workplace: what the practitioner needs to know about chemical exposures. Obstet Gynecol 1988;71:921-38.

8 Koren G, Chang N, Gonen R, et al. Lead exposure among mothers and their newborns in Toronto. Canadian Medical Association Journal 1990;142:1241-4.

9 Doull J, Klaasen CD, Amdur MO. Casarett and Doull's Toxicology. 2nd ed. New York: Macmillan Publishing Co, 1980;497-526.

10 Smith DS. Harmful chemicals and drugs in breast milk. Paediatrics in Review 1981;2:279-83.

11 Lowry RB. Alberta Children's Hospital Foundation helps all Albertans: genetics and congenital anomalies. Bulletin of the Hereditary Diseases Program of Alberta 1989;8:1-2.

12 Lowry RB, Thunem NY, Anderson-Redick WS. Clinical and community studies Alberta congenital anomalies surveillance system. Canadian Medical Association Journal 1989;141: $1155-9$.

13 Canadian Public Health Association. Birth defects in Canada. A pamphlet published in 1989 in cooperation with the laboratory centre for disease control, Ottawa: Health and Welfare Canada.

14 Bregman DJ, Anderson KE, Buffler P, Salg J. Surveillance for work-related adverse reproductive outcomes. Am J Public Health 1989;79:53-7.

15 National Research Council. Biologic markers in reproductive toxicology. Washington, DC: National Academy Press, 1989.

16 Johnson M. Did I begin? New Scientist 1989;1694:39-42.

17 Thomas JA, Ballantyne B. Occupational reproductive risks: sources, surveillance, and testing. J Occup Medicine 1990 32:547-53.

18 Sullivan P. CMA's discussion paper on fetal rights may spark debate. Canadian Medical Association Journal 1990;143: 404-5.

19 Ahlborg G. Pregnancy outcome among women working in laundries and dry cleaning shops using tetrachloroethylene. Am J Ind M 1990;17:567-75.

20 Huel G, Mergler D, Bowler R. Evidence for adverse reproductive outcomes among women microelectronic assembly workers. Br J Ind Med 1990;47:400-4.

21 Stücker I, Cailland J-F, Collin R, et al. Risk of spontaneous abortion among nurses handling antineoplastic drugs. Scand J Work Environ Health 1990;16:102-7.

22 Ahlborg GA Jr. Validity of exposure data obtained by questionnaire. Two examples from occupational reproductive studies. Scand J Work Environ Health 1990;16:284-8.

23 Beral V. Leukemia and nuclear installations; Occupational exposure of fathers to radiation may be the explanation. $B M$ 1990;300:411-12.

24 Brender JD, Suarez L. Paternal occupation and anencephaly. Am J Epidemiol 1990;131:517-21.

25 Lemasters GK, Samuels SJ, Morrison JA, Brooks SM Reproductive outcomes of pregnant workers employed at 36 reinforced plastics companies. J Occup Med 1989;31:115-20.

26 Olsham AF, Teschke K, Baird PA. Birth defects among offspring of firemen. Am Journal Epidemiol 1990;131:312-21.

27 McDonald AD, McDonald JC. Outcome of pregnancy in leather-workers. $B M J$ 1986;292:979-81.

28 Restrepo M, Munoz N, Day N, et al. Birth defects among children born to a population occupationally exposed to pesticides in Columbia. Scand $J$ Work Environ Health 1990;16:239-46.

29 Gardner MJ, Snee MP, Hall AJ, Powell CA, Downes S, Terrell JD. Results of case-control study of leukemia and lymphoma among young people near Sellafield nuclear plant in West Cumbria. $B M J$ 1990;300:423-29.

30 Gardner MJ, Hall AJ, Snee MD, et al. Methods and basic data of case-control study of leukemia and lymphoma among young people near Sellafield nuclear, plant in West Cambria. BMJ 1990;300:429-34.

31 Guirguis SS, Pelmear PL, Roy ML, Wong L. Health effects associated with exposure to anasthetic gases in Ontario hospital personnel. Br J Ind Med 1990;47:490-97.

32 Rajhans GS, Brown DA, Whaley D, Wong L, Guirguis SS Hygiene aspects of occupational exposure to waste anesthetic gases in Ontario hospitals. Ann Occup Hyg 1989;33:27-45.
33 Olsen GW, Lanham JM, Bodner KM, Hylton DB, Bond GG. Determinants of spermatogenesis recovery among workers exposed to 1,2-dibromo-3-chloropropane. J Occup Med 1990;32:979-84.

34 Levine RJ, Mathew RM, Chenault CR, et al. Differences in the quality of semen in outdoor workers during summer and winter. N Engl J Med 1990;323:12-16.

35 Wyrobek AJ. Male biomarkers of abnormal reproductive outcome. Health and Environment Digest 1990;4:1-4.

36 Warkany J. Congenital malformations. Chicago: Year Book Medical Publishers, 1971;84-95.

37 Rodier P. Structural-functional relationships in experimentally induced brain damage. Prog Brain Res 1988;73:335-48.

38 Manson JM. Development toxicity: changing factors, adapted from Pelkonen. Society of Toxicology continuing education course, 1990. Miami Beach, Florida, 29th Annual Meeting. Society of Toxicology Continuing Education Committee, $1990 ; 4-17$.

39 Working PK. Mutagenesis in germ cells. Chemical Institute of Industrial Toxicology Activities 1985;5:1-304.

40 Sadler TW. Developmental Toxicity. Society of Toxicology continuing education course 1990. (Lecture handouts)

41 Rodier PM. Structural-functional relationships in experimentally induced brain damage. Prog Brain Res 1988;73:335-48.

$42 \mathrm{Kellogg}$ CK. Benzodiazepines: influence on the developing brain. Prog Brain Res 1988;73:207-25.

43 Hill MR, Hegemier S, Tennyson LM. The fetal alcohol syndrome: a multihandicapped child. Neurotoxicology 1989; 10:585-96

44 Cranmer JM, Wiggins RC. Drug abuse and brain development: introduction and overview of the 6th international neurotoxicology conference. Neurotoxicology 1989;10:305-6.

45 Lindbohm $M-L$, Taskinen $H$, Sallmen $M$, Hemminki $K$. Spontaneous abortions among women exposed to organic solvents. Am J Ind Med 1990;17:449-63.

46 Bellinger D, Leviton A, Waternaux C, et al. Longitudinal analyses of prenatal and post-natal lead exposure and early cognitive development. $N$ Engl J Med 1987;316:1037-43.

47 Goyer RA. Transplacental transport of lead. Environ Health Perspect 1990;89:101-5.

48 Silbergeld EK. Toward the twenty-first century: lessons from lead and lessons yet to learn. Environ Health Perspect 1990;86:191-6.

49 Equal Employment Opportunity Commission guidelines on reproductive and fetal hazards. Washington, DC: Occupational Safety and Health Reporter. The Bureau of National Affairs Inc. 19 Oct 1988.

50 McElveen JC Jr, Jones JD, Day, Reavis, Pogue. Fetal protection policies. The Occupational and Environmental Medicine Report 1988;2:57-8.

51 Lowry F. VDTs and health: many studies, few answers. Canadian Medical Association Journal 1989;141:974-7.

52 Windham GC. Does using VDTs during pregnancy affect the fetus? Health and Environment Digest 1990;4:1-3.

53 Infectious Diseases and Immunization Committee, Canadian Paediatric Society. Cytomegalovirus infection in day-care centres: risks to pregnant women. Canadian Medical Association Journal 1990;142:547-8.

54 Commission de la santé du travail, Gouvernement du Quebec 1990 For a safe maternity experience. 730 , boulevard Charest Est, Quebec City.

55 Reproductive and cancer hazard assessment section. Approaches for identifying priority candidates for listing as reproductive/ developmental toxicants under proposition 65. Los Angeles, California: Office of Environmental Health Hazard Assessment, California Departmment of Health Services, March 1990.

56 Himmelstein JS and Frumkin H. The right to know about toxic exposures: implications for physicians. $N$ Engl J Med 1985;312:687-90.

57 Health and Welfare Canada. The pregnant worker-a resource document for health professionals. Ottawa: Public Affairs Directorate, 1986

58 Canadian Chemical Producers Association. Guidelines on reproductive and developmental hazards in the workplace. Ottawa: CCPA, 1991 Feb 1.

Accepted 3 June 1991 